\title{
Trace Metals in the Urban Aerosols of Rio de Janeiro City
}

\author{
Josiane Loyola, ${ }^{a}$ Graciela Arbilla, ${ }^{*, a}$ Simone L. Quiterio, ${ }^{a, b}$ Viviane Escaleira ${ }^{c}$ and Alan S. Minho ${ }^{d}$ \\ anstituto de Química, Universidade Federal do Rio de Janeiro, Centro de Tecnologia, \\ Prédio A, Sala 408, Cidade Universitária, 21949-900 Rio de Janeiro-RJ, Brazil \\ ${ }^{b}$ Instituto Federal de Educação, Ciência e Tecnologia do Rio de Janeiro, Campus Maracanã, \\ Rua Senador Furtado, 121, Maracanã, 20270-020 Rio de Janeiro-RJ, Brazil \\ ${ }^{c}$ Centro Nacional da Pesquisa do Solo, EMBRAPA, Rua Jardim Botânico, 1024, \\ 22460-000 Rio de Janeiro-RJ, Brazil
}

${ }^{d}$ CENPES/Petrobras, Av. Horácio Macedo, 950, Cidade Universitária, 21941-915 Rio de Janeiro-RJ, Brazil

\begin{abstract}
De janeiro a abril de 2009, amostras de partículas suspensas (TSP) e de materiais particulados $\left(\mathrm{PM}_{10}\right.$ e $\left.\mathrm{PM}_{2.5}\right)$ foram coletadas de uma área urbana característica altamente impactada pelo tráfego de veículos. As concentrações de metais nestas amostras foram determinadas por ICP-OES (espectroscopia de emissão por plasma indutivamente acoplado). $\mathrm{Ca}, \mathrm{Mg}, \mathrm{Fe}$ e $\mathrm{Al}$ foram os metais mais abundantes presentes em TSP e $\mathrm{PM}_{10}$, com concentrações maiores que $427 \mathrm{ng} \mathrm{m}^{-3}$. Em $\mathrm{PM}_{2.5}$, os metais mais abundantes foram Fe e $\mathrm{Ca}$ (307 e $60 \mathrm{ng} \mathrm{m}^{-3}$, respectivamente), enquanto que as concentrações de $\mathrm{Mg}$, $\mathrm{Zn}$ e $\mathrm{Cu}$ foram aproximadamente $20 \mathrm{ng} \mathrm{m}^{-3}$. Para $\mathrm{PM}_{10} \mathrm{ePM}_{2.5}$, correlações elevadas foram obtidas para $\mathrm{Ca}, \mathrm{Mg}$ e $\mathrm{Al}$, enquanto a correlação de $\mathrm{Ca}$ e $\mathrm{Mg}$ com $\mathrm{Fe}$ mostrou-se pobre, indicando assim que $\mathrm{Ca}, \mathrm{Mg}$ e $\mathrm{Al}$ provavelmente se originam principalmente da resuspensão de poeira, enquanto Fe pode ser também proveniente de uma fonte adicional, como o desgaste de freio. Elementos antropogênicos $(\mathrm{Zn} \mathrm{e} \mathrm{Cu}$ ) tiveram fatores de correlação baixos, sugerindo fontes de emissões diferentes. A presença de $\mathrm{Cu}$ pode estar relacionada com o desgaste dos freios e a de $\mathrm{Zn}$ pode ser atribuída ao desgaste do pneu. Em partículas finas, $\mathrm{Ca}, \mathrm{Mn}, \mathrm{Fe}, \mathrm{Zn}$ e $\mathrm{Cu}$ estavam presentes em razões mais elevadas do que em material da crosta. Uma vez que estas partículas são observadas principalmente devido aos processos de combustão, elas podem estar presentes na gasolina, óleo e lubrificantes. Fe foi correlacionado com Mn, enquanto fatores de correlação entre $\mathrm{Ca}$ e $\mathrm{Mg}$ foram relativamente baixos.
\end{abstract}

From January to April 2009, samples of suspended particles (TSP) and particulate matters $\left(\mathrm{PM}_{10}\right.$ and $\left.\mathrm{PM}_{2.5}\right)$ were collected from a well-characterized urban area that is highly impacted by vehicular traffic. The metal concentrations in these samples were determined using ICP-OES (inductively coupled plasma-optical emission spectroscopy). $\mathrm{Ca}, \mathrm{Mg}, \mathrm{Fe}$ and $\mathrm{Al}$ were the most abundant metals present in TSP and $\mathrm{PM}_{10}$, with concentrations higher than $427 \mathrm{ng} \mathrm{m}^{-3}$. In $\mathrm{PM}_{2.5}$, the most abundant metals were $\mathrm{Fe}$ and $\mathrm{Ca}$ (307 and $60 \mathrm{ng} \mathrm{m}^{-3}$, respectively), while the concentrations of $\mathrm{Mg}, \mathrm{Zn}$ and $\mathrm{Cu}$ were approximately $20 \mathrm{ng} \mathrm{m}^{-3}$. For $\mathrm{PM}_{10}$ and $\mathrm{PM}_{25}$, high correlations were obtained for $\mathrm{Ca}, \mathrm{Mg}$ and $\mathrm{Al}$, while the correlation of $\mathrm{Ca}$ and $\mathrm{Mg}$ with $\mathrm{Fe}$ was poor, thereby indicating that $\mathrm{Ca}, \mathrm{Mg}$ and $\mathrm{Al}$ probably originate mainly from the resuspension of dust, while Fe may also be originated from an additional source, such as brake wear. Anthropogenic elements $(\mathrm{Zn}$ and $\mathrm{Cu})$ had low correlation factors, suggesting different emission sources. The presence of $\mathrm{Cu}$ may be linked to the abrasion of brakes, and $\mathrm{Zn}$ may be attributed to tire wear. In fine particles, $\mathrm{Ca}, \mathrm{Mn}, \mathrm{Fe}$, $\mathrm{Zn}$ and $\mathrm{Cu}$ were present in higher ratios than in crustal material. Because these particles are mainly observed due to the combustion processes, they may be present in gasoline, oil and lubricants. $\mathrm{Fe}$ was correlated with $\mathrm{Mn}$, while correlation factors between $\mathrm{Ca}$ and $\mathrm{Mg}$ were relatively lower.

Keywords: total particulate matter, $\mathrm{PM}_{10}, \mathrm{PM}_{2.5}$, trace metals, vehicle emissions 


\section{Introduction}

The most commercialized automotive fuels in Brazil are gasohol, ethanol, diesel and compressed natural gas (CNG). Recently, the first national vehicular emission inventory was published with data that was current up to 2009. ${ }^{1}$ According to these data, the national fleet consists of $c a .36$ million vehicles with $59 \%$ light-duty vehicles, $27 \%$ motorcycles, $10 \%$ commercial light vehicles and $4 \%$ heavy-duty vehicles (buses and trucks). Light vehicles are mostly run on gasohol (57\%) or are flex-fueled (37\%). Motorcycles are generally fueled with gasohol (98\%), and commercial light vehicles use gasohol $(42 \%)$ or diesel $(28 \%)$ or are flex-fueled $(26 \%)$. Gasohol is a blend of gasoline and ethanol (24\%) containing a complex mixture of hydrocarbons, such as paraffin, naphthene, olefin and aromatic hydrocarbon, which are composed between 4 and 12 carbons and are derived from crude petroleum with a small amount of additives.

The Rio de Janeiro Metropolitan Area has the secondlargest running fleet with $c a$. 3.3 million vehicles. ${ }^{2}$ According to the most recent available official emission inventory, ${ }^{3} \mathrm{ca}$. $76 \%$ of the total air pollution caused by $\mathrm{CO}, \mathrm{SO}_{2}, \mathrm{NO}_{\mathrm{X}}$ and $\mathrm{PM}_{10}$ (particulate matter) are direct contributions from mobile sources. According to the national emission inventory, $96 \%$ of emitted particulate matter from vehicles results from diesel exhaust. ${ }^{1}$

National standards of air quality only determine limits for total particulate matter $\left(240 \mu \mathrm{g} \mathrm{m}^{-3}\right.$ for $24 \mathrm{~h}$ and $80 \mu \mathrm{g} \mathrm{m}^{-3}$ for the annual geometric mean) and $\mathrm{PM}_{10}$ $\left(150 \mu \mathrm{g} \mathrm{m}^{-3}\right.$ for $24 \mathrm{~h}$ and $50 \mu \mathrm{g} \mathrm{m}^{-3}$ for the annual arithmetic mean). ${ }^{4}$ However, there is no legislation regarding fine particles $\left(\leq \mathrm{PM}_{2.5}\right)$, and the monitoring was only recently initiated in some locations that have been characterized for exhibiting critical air quality conditions.

In a recent review, Korn et al. ${ }^{5}$ discussed an analytical method developed for metal and metalloid quantification in automotive fuels. As described in that review, certain metals, such as nickel and vanadium, are natural constituents of petroleum and are found in small concentrations in petroleum-derived products. ${ }^{5}$ Other metals, such as iron and zinc, are used in the manufacturing of fuel tanks and may be transferred to fuels during transport and storage. In addition, other metals are introduced in the refinement process or are introduced as additives to promote the desired characteristics. These deliberately introduced metals include $\mathrm{Al}, \mathrm{Ca}, \mathrm{Ce}, \mathrm{Cr}, \mathrm{Co}, \mathrm{Cu}, \mathrm{La}, \mathrm{Pb}, \mathrm{Li}, \mathrm{Mg}, \mathrm{Mn}, \mathrm{Mo}$, $\mathrm{Ni}, \mathrm{Si}, \mathrm{Ag}, \mathrm{Na}, \mathrm{Tl}, \mathrm{Sn}, \mathrm{W}, \mathrm{V}, \mathrm{Zn}$ and $\mathrm{Zr}^{6-8}$

In previous studies, emissions of coarse particles were found to be dominated by the resuspension of dust and brake wear, while fine particles were mainly due to combustion processes. ${ }^{9}$ The various trace metal sources in fine particulate matter emitted from road traffic were characterized in a road tunnel in Nice, France. ${ }^{10}$ Using a multivariate analysis (positive matrix factorization), the contribution of the sub-sources were determined as follows: resuspension (43\%), vehicular abrasion (36\%) and fuel combustion (21\%). Resuspended dust may be of anthropogenic or natural origin and is not generally considered in emission inventories.

Metal content in airborne particulate matter collected in the Rio de Janeiro Metropolitan Area was primarily determined in TSP (total suspended particles) and $\mathrm{PM}_{10}{ }^{11-13}$ Over the last few years, several studies describing the $\mathrm{PM}_{2.5}$ particulate matter were obtained in Rio de Janeiro City. ${ }^{14,15}$ In 2009, Godoy et al. ${ }^{15}$ published results describing aerosol samples that were collected in ten locations in the Rio de Janeiro Metropolitan Area, and the trace elements were analyzed by inductively coupled plasmamass spectrometry (ICP-MS). After applying multivariate analysis, Godoy et al. ${ }^{15}$ concluded that soil dust is the main source of coarse aerosol particles, with sea-spray and vehicular traffic being the next most common sources. However, for the $\mathrm{PM}_{2.5}$ fraction, the anthropogenic sources, such as vehicular traffic and oil combustion, accounted for $c a$. $65 \%$. Similar studies were also performed for Campinas ${ }^{16}$ and São Paulo Cities. ${ }^{17,18}$

In a recent study, ${ }^{13}$ TSP and $\mathrm{PM}_{10}$ samples were collected at the Major José Carlos Lacerda Bus Station in Duque de Caxias City (Rio de Janeiro Metropolitan Area) where buses were the only significant emission sources, representing $\mathrm{ca}$. $98 \%$ of the total flux. $\mathrm{Ca}, \mathrm{Mg}$, $\mathrm{Fe}$ and $\mathrm{Al}$ were the most abundant elements, accounting for ca. 50.1, 24.2, 6.5 and $18.7 \%$ of the total metal content, respectively. With the exception of a few samples, Co, $\mathrm{Ni}, \mathrm{Cd}, \mathrm{Cr}$ and $\mathrm{Pb}$ levels were below limits of detection. Calculated enrichment factors showed that $\mathrm{Zn}$ and $\mathrm{Cu}$ likely originated from fuel and oil compositions. Ca, $\mathrm{Mg}$ and $\mathrm{Al}$ may be attributed to dust resuspension, while Fe may originate from both dust resuspension and vehicular contributions.

The goal of this work was to characterize the metal content of particulate matter at an urban location that is strongly influenced by vehicular traffic and to suggest the metal sources. However, it should be noted that these results are limited, as they are strongly affected by the vehicle operating conditions, quality of fuels, meteorological parameters and air transport. The sampling and analyses were performed using the same conditions as those used in the previous study of diesel emissions, ${ }^{13}$ thereby enabling a comparison of the results. 


\section{Experimental}

\author{
Sampling site
}

The city occupies an area of 1,200.3 $\mathrm{km}^{2}$ and has a population of $6,320,446$ inhabitants $^{19}$ and approximately $2,416,823$ vehicles. ${ }^{20}$ Gasohol is used by $50.85 \%$ of the vehicles (gasoline with $24.00 \%$ ethanol), neat ethanol $8.95 \%$, compressed natural gas $16.03 \%$ (CNG), flex-fueled (gasohol and ethanol) cars are $19.50 \%$ of the vehicles (gasohol and ethanol) and diesel $3.97 \% .^{20}$

Sampling was conducted in an urban area that was strongly affected by vehicle emissions at Jardim Botanico Street, which is a busy roadway that provides access to the André Rebouças Tunnel and links the Jardim Botanico and Rodrigo de Freitas Lagoon neighborhoods, from Southern district of the city to the Northern areas. Samplers were placed $c a .145 \mathrm{~m}$ from the entrance of the tunnel and $c a .5 \mathrm{~m}$ from the street in an open area of the tunnel administrative building. The administrative building is constructed of concrete, and the samplers were placed more than $50 \mathrm{~m}$ from the walls. The tunnel is two-bored and has two galleries, one of which is $2040 \mathrm{~m}$ long and connects Jardim Botanico and Cosme Velho, while the other gallery is $800 \mathrm{~m}$ long and connects Cosme Velho and Rio Comprido. ${ }^{21}$ The flux of vehicles is almost constant during the daylight hours and is approximately eight times greater than the flux observed at night. In the South entrance, where the samples were collected, the mean traffic from 7 a.m. to 7 p.m. on Mondays through Fridays was ca. 5,500 vehicles per h. Light-duty vehicles represent ca. $97 \%$ of the total flux, and the distribution by fuel type is similar to the mean distribution for Rio de Janeiro. A map of the area (Figure S1) is available in the Supplementary Information section.

The sampling area is mainly affected by vehicular emissions, though the resuspension of dust and marine aerosol should also be considered. Data collected by the INEA (Rio de Janeiro State Environmental Institute, Brazil) show that industrial facilities are mainly located in the Western and Northern districts of the metropolitan area. ${ }^{3}$ Climatological evaluation of the wind patterns for Rio de Janeiro City shows a larger frequency of the South-Southeast to North-Northwest winds in virtually every month of the year, with an average wind speed of $8 \mathrm{~km} \mathrm{~h}^{-1}$. Data collected in downtown neighborhoods during the year of 2009 showed a predominance of weak winds in the Southeast and Northwest directions. ${ }^{3}$ The frequencies of winds over the sampling period were plotted by wind directions to show the direction with the greatest frequency. The data were collected in the Santos Dumont
Airport and showed a predominance of winds from the Southeast $\left(135^{\circ}\right)$ to Northwest $\left(180^{\circ}\right)$ and wind speeds ranging up to $30 \mathrm{~km} \mathrm{~h}^{-1}$. The Santos Dumont Airport is located adjacent to the Guanabara Bay, being approximately $1 \mathrm{~km}$ from downtown and $9 \mathrm{~km}$ from the sampling area. The wind rose (Figure S2) is shown in the Supplementary Information section.

The air circulation in the Rio de Janeiro Metropolitan Area is largely affected by topographical conditions. The Tijuca Forest (a mountainous rainforest area) forms a natural barrier to air circulation and divides the city into Northern and Southern sections. Using topographical and meteorological criteria, the Rio de Janeiro Metropolitan Area was divided into four air basins. ${ }^{3}$ The sampling area was located in Air Basin II, while the main industrial facilities were located in Basins I (West) and III (North). Considering the geographical position of the sampling site and the physical barrier of Pedra Branca and Tijuca Mountains, the sampling site mainly receives marine and urban air from the South and only a small contribution from the industrial areas.

\section{Sampling}

The selection of the points and the sampling procedures took into account the minimum sampler siting criteria, calibration and filter handling procedures recommended by the U. S. Environmental Protection Agency (U.S. EPA). ${ }^{22}$ Briefly, following EPA recommendations, the height above ground should be 2 to $7 \mathrm{~m}$, the distance from samples to obstacles should be at least twice the height of the obstacle and the air flow around the sampler inlet should be unrestricted.

TSP and $\mathrm{PM}_{10}$ were collected using high-volume samplers (Sibata, model HVC500) and borosilicate glass microfiber filters (Sibata, diameter of $110 \mathrm{~mm}$, thickness of $0.40 \mathrm{~mm}$ and porosity of $0.6 \mu \mathrm{m})$. The flow rate was $0.5 \mathrm{~m}^{3} \mathrm{~min}^{-1}$. A total of 62 samples (31 TSP and $31 \mathrm{PM}_{10}$ samples) was collected on weekdays without rainfall in the period of January to April 2009.

$\mathrm{PM}_{2.5}$ was collected using a high volume sampler (Hi-vol, Energetica) that was equipped with an impactor design size-select inlet (Andersen, model G1200-2.5) and quartz fiber filters (Millipore filters with an area of $20 \times 25 \mathrm{~cm}$ and a thickness of $0.5 \mathrm{~mm}$ ). The flow rate was 1.05 to $1.21 \mathrm{~m}^{3} \mathrm{~min}^{-1}$. A total of 50 samples was collected during weekdays and Saturdays during the period of January to April 2009.

Samplings of TSP and $\mathrm{PM}_{10}$ were performed at a height of $4 \mathrm{~m}$ using $6 \mathrm{~h}$ sampling periods (from 8 a.m. to 2 p.m.). $\mathrm{PM}_{2.5}$ samples were collected at a height of $2 \mathrm{~m}$ 
over $24 \mathrm{~h}$. It was not the objective of this study to assess such comparisons as rush and non-rush hours, weekdays to Saturdays and Sundays or daytime to nighttime periods. Although these comparisons would be useful in clearly linking the metal content to gasohol, experiments at night and during the weekends were not possible due to security reasons and restricted access to equipment.

\section{Extraction procedure and analysis}

The levels of TSP, $\mathrm{PM}_{10}$ and $\mathrm{PM}_{2.5}$ were determined by gravimetry using an electronic microbalance with a $1 \mu \mathrm{g}$ sensitivity. For the analysis of trace metals, the same procedures were followed as in our previous studies. ${ }^{12,13,23}$ The filters were extracted by adding $5 \mathrm{~mL}$ of nitric acid (Merck Suprapur 65\%), $2 \mathrm{~mL}$ of hydrochloric acid (Merck Suprapur $36 \%$ ) and $10 \mathrm{~mL}$ of ultrapure water (18 $\mathrm{M} \Omega \mathrm{cm}^{-1}$ of specific resistivity) to a Pyrex tube and subsequently heating for $2 \mathrm{~h}$ at $95^{\circ} \mathrm{C}$ on a heating plate. The extracted solution was filtered with a Whatman No. 41 (WH1441-110) filter, diluted to a volume of $20 \mathrm{~mL}$ with ultrapure water and stored in pre-cleaned polyethylene bottles in the refrigerator for further analyses.

The metals were determined by ICP-OES (inductively coupled plasma-optical emission spectroscopy) following Method IO-3.4. Limits of detection and accuracy were determined using the same method. ${ }^{24}$ Data quality, accuracy and reproducibility, and limits of detection and quantification were determined using the same procedures as the used in our previous study at the bus station. ${ }^{13}$

Limits of detection and quantification computed as three and ten times, respectively, the standard deviation of the distribution of outputs for ten repeated measurements of the standard, which contained no metals..$^{25}$ These limits of detection were calculated as $30 \mathrm{ng} \mathrm{m}^{-3}$ for $\mathrm{Ca}, 20 \mathrm{ng} \mathrm{m}^{-3}$ for $\mathrm{Mg}$ and $\mathrm{Ni}, 35 \mathrm{ng} \mathrm{m}^{-3}$ for $\mathrm{Al}, 3 \mathrm{ng} \mathrm{m}^{-3}$ for $\mathrm{Cu}, 40 \mathrm{ng} \mathrm{m}^{-3}$ for $\mathrm{Fe}$ and $\mathrm{Pb}, 1 \mathrm{ng} \mathrm{m}^{-3}$ for $\mathrm{Mn}, \mathrm{Zn}$ and $\mathrm{V}, 7 \mathrm{ng} \mathrm{m}^{-3}$ for $\mathrm{Cr}$ and $\mathrm{Co}, 2 \mathrm{ng} \mathrm{\textrm {m } ^ { - 3 }}$ for $\mathrm{Cd}$ and $9 \mathrm{ng} \mathrm{m}^{-3}$ for Mo.

The accuracy of the method was evaluated using a standard reference material (SRM, 2783 Air Particulate on Filter Media, National Institute of Standards and Technology (NIST), Maryland, U. S. A.). Three samples of the reference material were analyzed in triplicate, and the results were compared with the concentrations reported in the certificate of analysis. The obtained concentrations differed by less than $8 \%$. All samples and SRM were determined in triplicate, and a difference of less than $1 \%$ was considered acceptable.

Filter and reagent blanks were processed following the same procedure. The metal content of the blanks for $\mathrm{Ca}$, $\mathrm{Mg}, \mathrm{Mn}, \mathrm{Fe}, \mathrm{Zn}, \mathrm{Cu}, \mathrm{Cr}, \mathrm{Co}, \mathrm{Ni}, \mathrm{Al}, \mathrm{Cd}, \mathrm{Pb}, \mathrm{Mo}$ and $\mathrm{V}$ was less than $5 \%$ of the sample average contents. For $\mathrm{Cr}$, the metal content represented less than $8 \%$.

\section{Statistical analysis}

Experimental data were analyzed using Statistica 7.0 (StatSoft). The data were previously analyzed using descriptive statistics. After removing outliers, a multivariate statistical analysis was performed that included the evaluation of Spearman's correlation coefficients, cluster analysis (CA) using Euclidian distances and Ward's method and principal component analysis (PCA).

\section{Results and Discussion}

$\mathrm{PM}_{10}$ and total particulate matter

TSP levels were in the range of 35.04 to $95.6 \mu \mathrm{g} \mathrm{m}^{-3}$. The mean concentration for all samples $(\mathrm{n}=31)$ was $53.7 \mu \mathrm{g} \mathrm{m}^{-3}$. Similarly, values for $\mathrm{PM}_{10}(\mathrm{n}=31)$ ranged from 13.1 to $47.0 \mu \mathrm{g} \mathrm{m}^{-3}$ with a mean value of $22.9 \mu \mathrm{g} \mathrm{m}^{-3}$.

Because TSP and $\mathrm{PM}_{10}$ samples were simultaneously collected using Sibata portable samplers, their levels may be directly compared. The $\mathrm{PM}_{10} / \mathrm{TSP}$ ratios calculated for the same sampling date were in the range of 0.30 to 0.75 with an average value of 0.42 . In a previous study, ${ }^{13}$ the $\mathrm{PM}_{10} / \mathrm{TSP}$ ratios for a location with $95 \%$ diesel vehicles were calculated to be in the range of 0.11 to 0.65 with an average value of 0.24 . The coarse mode is mainly related to primary particles that are usually mechanically-generated. So, the main contribution to particulate matter in the TSP and $\mathrm{PM}_{10}$ range is from the resuspension of dust and particles from natural sources (plants, microorganisms and ocean spray). ${ }^{26}$ This is due to the proximity of the Jardim Botanico Park, Tijuca Forest, Rodrigo de Freitas Lagoon and the Atlantic Ocean.

\section{Fine particulate matter}

$\mathrm{PM}_{2.5}$ levels were also determined by gravimetry. The values for $\mathrm{PM}_{2.5}(\mathrm{n}=50)$ ranged from 7.6 to $117.2 \mu \mathrm{g} \mathrm{m}^{-3}$ with a mean value of $29.2 \mu \mathrm{g} \mathrm{m}^{-3}$. Fine particles may be secondary in origin, being generated by chemical reactions between gases and particles, or primary in origin, being generated by combustion processes ${ }^{26}$ Marine aerosols may also contain fine particles $(5-10 \%)$ that result from the evaporation of sea-spray produced by bursting bubbles or wind-induced wave breaking. Other probable sources of particles smaller than $2.5 \mu \mathrm{m}$ in diameter include tire wear and brake linings. 


\section{Levels of trace metals}

Fourteen metals were analyzed in the samples: $\mathrm{Ca}, \mathrm{Mg}$, $\mathrm{Mn}, \mathrm{Fe}, \mathrm{Zn}, \mathrm{Cu}, \mathrm{Co}, \mathrm{Ni}, \mathrm{Al}, \mathrm{Cd}, \mathrm{Cr}, \mathrm{Pb}, \mathrm{Mo}$ and V. Mean concentrations, standard derivations, minima and maxima are shown in Table 1.

$\mathrm{Ca}, \mathrm{Mg}, \mathrm{Fe}$ and $\mathrm{Al}$ were the most abundant metals in TSP and $\mathrm{PM}_{10}$ with mean concentrations higher than $427 \mathrm{ng} \mathrm{m}^{-3}$. In $\mathrm{PM}_{2.5}$, the most abundant metals were Fe and $\mathrm{Ca}$ (307 and $60 \mathrm{ng} \mathrm{m}^{-3}$, respectively), while $\mathrm{Mg}, \mathrm{Zn}$ and $\mathrm{Cu}$ were detected at similar levels (ca. 20-35 $\mathrm{ng} \mathrm{m}^{-3}$ ). All concentrations were under the limits of detection. These results agree with those seen by Lough et al.,${ }^{27}$ who reported that the most abundant elements found in $\mathrm{PM}_{10}$ in two tunnels in Milwaukee (U. S. A.) were Fe, Ca, Si, Na, $\mathrm{Mg}, \mathrm{Al}, \mathrm{S}$ and $\mathrm{K}$. These accounted for an average of $94 \%$ of the total $\mathrm{PM}_{10}$ content for the 42 measured elements. These metals were also present in $\mathrm{PM}_{2.5}$ in much lower amounts and were significantly different from the limits of detection in few samples. ${ }^{27}$

For $\mathrm{PM}_{10}$, the average metal contents were 55.7,14.9, 8.0 and $18.5 \%$ for $\mathrm{Ca}, \mathrm{Mg}, \mathrm{Al}$ and $\mathrm{Fe}$, respectively. The values determined for the diesel emissions were 50.2, $24.1,18.7$ and $6.5 \%$, respectively for the same metals. ${ }^{13}$ The differences are probably due to the composition of soils, aerosol particles, mechanical parts and, also, to the composition of fuels.

To compare the results of the atmospheric particulate matter with motor emissions, the exhaust of a 1.8 gasohol engine was analyzed using the ABNT NBR 6601:2005 Protocol. The engine was operated with the gasohol that is currently used in Brazil. Two samples (one of TSP and the other of $\mathrm{PM}_{10}$ ) were collected. In the TSP sample, the following metals were detected: $\mathrm{Ca}(52.0 \%), \mathrm{Mg}(26.7 \%)$, $\mathrm{Fe}(1.5 \%), \mathrm{Zn}(0.1 \%), \mathrm{Cu}(1.6 \%)$ and $\mathrm{Al}(18.1 \%)$. In the $\mathrm{PM}_{10}$ sample, the following metals were detected: $\mathrm{Ca}$ (51.6\%), $\mathrm{Mg}$ (26.9\%), Fe (0.8\%), Zn (0.1\%), Cu (1.9\%) and $\mathrm{Al}(18.7 \%)$. Because of operational restrictions, it was not possible to collect more samples for the purpose of studying the $\mathrm{PM}_{2.5}$ emissions.

The results obtained for the engine exhaust were notably different from those obtained for the atmospheric particulate matter, and this conclusion should be confirmed with further experiments. For TSP, the concentration ratios of metal/ Ca were $0.51,0.03,0.35$ and 0.002 for $\mathrm{Mg}, \mathrm{Fe}, \mathrm{Al}$ and $\mathrm{Zn}$, respectively, in the motor exhaust, and $0.26,0.81$, 0.22 and 0.02 for the same metals in the ambient aerosol. Clearly, the $\mathrm{Zn}$ and Fe contents were higher for the airborne particulate samples, indicating that there are other sources of these metals. As reported by Thorpe and Harrinson, ${ }^{28} \mathrm{Fe}$ is present in high concentrations in car brake linings and car brake dust, and $\mathrm{Zn}$ is usually associated with tire wear. ${ }^{29}$ $\mathrm{Mg}$ and $\mathrm{Al}$ are present in relatively high concentrations in motor exhaust. For $\mathrm{PM}_{10}$ samples, a similar conclusion may be obtained.

The results for the TSP and $\mathrm{PM}_{10}$ samples were significantly different from those obtained for fine particles in which $\mathrm{Ca}, \mathrm{Mg}, \mathrm{Al}$ and $\mathrm{Fe}$ represent 14.2, 4.5, 3.9 and $61.9 \%$ of the total metal content, respectively. This finding may be due to the different sources of these metals. Ca, $\mathrm{Mg}$ and $\mathrm{Al}$ are mainly related to soil dust and marine aerosols, while Fe may also be related to combustion

Table 1. Statistical summary of metal concentrations determined in TSP, $\mathrm{PM}_{10}$ and $\mathrm{PM}_{2.5}$. Samples were collected in the André Rebouças Tunnel in the period of January-April 2009. Standard deviations (SD), minimum (Min.) and maximum (Max.) values are also shown

\begin{tabular}{|c|c|c|c|c|c|c|c|c|c|c|}
\hline & & \multicolumn{9}{|c|}{ Concentration / $\left(\mathrm{ng} \mathrm{m}^{-3}\right)$} \\
\hline & & $\mathrm{Ca}$ & $\mathrm{Mg}$ & Mn & $\mathrm{Fe}$ & $\mathrm{Zn}$ & $\mathrm{Cu}$ & $\mathrm{Cr}$ & $\mathrm{Al}$ & $\mathrm{V}$ \\
\hline TSP & Mean & 5038 & 1320 & 54 & 4101 & 128 & 179 & 13 & 1095 & 7 \\
\hline \multirow[t]{3}{*}{$(\mathrm{n}=33)$} & SD & 1285 & 297 & 14 & 1068 & 29 & 29 & 3 & 309 & 3 \\
\hline & Min. & 2878 & 744 & 30 & 2479 & 73 & 130 & 8 & 527 & 4 \\
\hline & Max. & 7800 & 1933 & 90 & 6490 & 182 & 253 & 19 & 1804 & 16 \\
\hline $\mathrm{PM}_{10}$ & Mean & 2997 & 803 & 14 & 994 & 39 & 87 & $<\mathrm{LOD}^{\mathrm{a}}$ & 427 & 5 \\
\hline \multirow[t]{3}{*}{$(\mathrm{n}=33)$} & SD & 981 & 252 & 5 & 314 & 18 & 25 & $<\mathrm{LOD}^{\mathrm{a}}$ & 133 & 3 \\
\hline & Min. & 811 & 244 & 5 & 418 & 17 & 58 & $<\mathrm{LOD}^{\mathrm{a}}$ & 124 & 1 \\
\hline & Max. & 4867 & 1256 & 24 & 1779 & 94 & 167 & $<\mathrm{LOD}^{\mathrm{a}}$ & 660 & 10 \\
\hline $\mathrm{PM}_{2.5}$ & Mean & 60 & 21 & 5 & 307 & 20 & 35 & $<\mathrm{LOD}^{\mathrm{a}}$ & $<\mathrm{LOD}^{\mathrm{a}}$ & 2 \\
\hline \multirow[t]{3}{*}{$(\mathrm{n}=50)$} & SD & 25 & 9 & 2 & 94 & 10 & 29 & $<\mathrm{LOD}^{\mathrm{a}}$ & $<\mathrm{LOD}^{\mathrm{a}}$ & 1 \\
\hline & Min. & 28 & 9 & $<\mathrm{LOD}^{\mathrm{a}}$ & 183 & 6 & 16 & $<\mathrm{LOD}^{\mathrm{a}}$ & $<\mathrm{LOD}^{\mathrm{a}}$ & $<\mathrm{LOD}^{\mathrm{a}}$ \\
\hline & Max. & 143 & 51 & 11 & 570 & 42 & 135 & $<\mathrm{LOD}^{\mathrm{a}}$ & $<\mathrm{LOD}^{\mathrm{a}}$ & 4 \\
\hline
\end{tabular}

${ }^{\mathrm{a}} \mathrm{LOD}$ : limit of detection 
sources. High concentrations of Fe were observed by Silva $^{29}$ in the exhaust of diesel and gasoline engines and were attributed to the corrosion of internal components and exhaust pipes.

For the TSP and $\mathrm{PM}_{10}$ samples, $\mathrm{Co}, \mathrm{Ni}, \mathrm{Cd}, \mathrm{Pb}$ and Mo were always observed in concentrations lower than their limits of detection. Cr was only observed in TSP samples. In our previous study ${ }^{13}$ in which TSP and $\mathrm{PM}_{10}$ samples were collected at the bus station, $\mathrm{Mn}, \mathrm{Co}, \mathrm{Ni}, \mathrm{Cd}$, $\mathrm{Cr}$ and $\mathrm{Pb}$ levels were under the limits of detection in all, but a few samples. It should be noted that in our previous work, ${ }^{13}$ final sample volumes of $50 \mathrm{~mL}$ were used. In the present work, smaller final sample volumes were adopted $(20 \mathrm{~mL})$, but the trace metal concentrations were still too low to be determined. A more sensitive method of detection was not available.

The pattern observed in the atmospheric particulate matter may be attributed to the influence of several sources, such as tail pipe emissions, brake wear, tire wear, resuspended dust and marine aerosols.

$\mathrm{Ca}, \mathrm{Mg}, \mathrm{Fe}$ and $\mathrm{Al}$ are major components of crustal materials and soil and, are predominantly attributed to the resuspension of dust. ${ }^{30}$ Road dust and roadside soils are often enriched with many elements emitted from anthropogenic sources, including $\mathrm{Pb}, \mathrm{Cu}, \mathrm{Cd}$ and $\mathrm{Zn}^{28}$ For $\mathrm{PM}_{10}$ and total particulate matter, $\mathrm{Zn}$ and $\mathrm{Cu}$ are present in all of the samples in much higher ratios than the ratios found in crustal materials, indicating that these two elements (which are anthropogenic in origin) are enriched in the soil (Table 2).

Additionally, $\mathrm{Ca}$ and $\mathrm{Mg}\left(\mathrm{PM}_{10}\right)$ and $\mathrm{Fe}$ (TSP) are present in higher ratios in the samples than in typical crustal material, which may indicate that vehicles also contribute to the emissions of these elements. It was reported that brake wear emissions contain significant amounts of metals, mainly $\mathrm{Fe}, \mathrm{Cu}, \mathrm{Zn}, \mathrm{Ca}$ and $\mathrm{Mn}{ }^{28}$ and $\mathrm{Zn}$ is usually considered a fingerprint of tire wear. ${ }^{30}$

Additionally, metal-based oil additives containing $\mathrm{Zn}$ and $\mathrm{Mg}$, Zn-based anti-wear agents and $\mathrm{Ca}-$ and Mg-based detergents are added to fuels and lubricating oils, influencing the sizes of emitted particles and their composition. ${ }^{31}$

Our previous results from studies ${ }^{13}$ at the bus station (TSP and $\mathrm{PM}_{10}$ ) showed that for diesel emissions, Fe and $\mathrm{Al}$ were not enriched in the soil and were probably not due to vehicle emissions.

For fine particles, $\mathrm{Mn}, \mathrm{Fe}, \mathrm{Zn}$ and $\mathrm{Cu}$ were presentin higher ratios than in crustal material. Because these particles mainly originate from combustion processes, being present in gasoline, oil and lubricants. $\mathrm{Al}, \mathrm{Cr}, \mathrm{Co}, \mathrm{Ni}, \mathrm{Cd}, \mathrm{Pb}$ and Mo were always observed in lower concentrations than their limits of detection. As previously observed ${ }^{29} \mathrm{Cu}, \mathrm{Cr}$, $\mathrm{Fe}, \mathrm{Mn}, \mathrm{Pb}$ and $\mathrm{Zn}$ were present in the exhaust of gasolinefueled vehicles, while $\mathrm{Cd}, \mathrm{Cu}, \mathrm{Pb}$ and $\mathrm{Zn}$ were found in alcohol engine emissions and $\mathrm{Cr}, \mathrm{Cu}$ and $\mathrm{Zn}$ were also found in additives. $\mathrm{Cu}, \mathrm{Fe}, \mathrm{Pb}$ and $\mathrm{Ni}$ were determined by electrothermal atomic absorption spectrometry in Brazilian gasoline..$^{32}$ The presence of metals in automotive fuels is associated with the corrosion of engine parts, deposition and oxidative decomposition reactions of the fuel compounds. ${ }^{33-35} \mathrm{Zn}$ may also originate from the production process of ethanol and the transportation and storage of the fuel. ${ }^{29}$

\section{Enrichment factors}

For TSP and $\mathrm{PM}_{10}$ samples, enrichment factors (EF) relative to the earth crust were calculated using $\mathrm{Al}$ as a

Table 2. Typical crust concentration (second column) and relative concentration of each metal in the earth crust (third column). Relative concentration of each crust metal in TSP, $\mathrm{PM}_{10}$ and $\mathrm{PM}_{2.5}$ samples (fourth, fifth and sixth columns). Enrichment factors (EF) for each metal in TSP, PM 10 and $\mathrm{PM}_{2.5}$ samples (three last columns) were calculated using $\mathrm{Al}$ and $\mathrm{Mg}$ as references for TSP/PM ${ }_{10}$ and $\mathrm{PM}_{2.5}$ samples, respectively

\begin{tabular}{|c|c|c|c|c|c|c|c|c|}
\hline Metals & $\begin{array}{c}\text { Crust concentration / } \\
\text { ppb by weight }\end{array}$ & $\begin{array}{l}\% \text { of metal } \\
\text { crust }\end{array}$ & $\begin{array}{c}\% \text { of metal } \\
\text { in TSP }\end{array}$ & $\begin{array}{c}\% \text { of metal } \\
\text { in } \mathrm{PM}_{10}\end{array}$ & $\begin{array}{c}\% \text { of metal } \\
\text { in } \mathrm{PM}_{2.5}\end{array}$ & $\begin{array}{c}\mathrm{EF}^{\mathrm{b}} \\
\text { in TSP }\end{array}$ & $\begin{array}{c}\mathrm{EF}^{\mathrm{b}} \\
\text { in } \mathrm{PM}_{10}\end{array}$ & $\begin{array}{c}\mathrm{EF}^{\mathrm{c}} \\
\text { in } \mathrm{PM}_{2.5}\end{array}$ \\
\hline $\mathrm{Ca}$ & $5.0 \times 10^{7}$ & 22.1 & 42.2 & 55.7 & 14.2 & 7.8 & 11.8 & 1.8 \\
\hline $\mathrm{Mg}$ & $2.9 \times 10^{7}$ & 12.8 & 10.8 & 14.9 & 4.5 & 3.1 & 4.9 & 1.0 \\
\hline $\mathrm{Mn}$ & $1.1 \times 10^{6}$ & 0.5 & 0.5 & 0.3 & 0.9 & 1.9 & 2.8 & 7.1 \\
\hline $\mathrm{Fe}$ & $6.3 \times 10^{7}$ & 27.9 & 34.3 & 18.5 & 62.0 & 5.4 & 3.3 & 8.4 \\
\hline $\mathrm{Zn}$ & $7.9 \times 10^{4}$ & a & 1.1 & 0.8 & 4.6 & 259.6 & 192.1 & 835.2 \\
\hline $\mathrm{Cu}$ & $6.8 \times 10^{4}$ & a & 1.5 & 1.7 & 8.8 & 191.2 & 238.4 & 1001.5 \\
\hline $\mathrm{Cr}$ & $1.4 \times 10^{5}$ & a & 0.1 & - & - & 4.1 & - & - \\
\hline $\mathrm{Al}$ & $8.2 \times 10^{7}$ & 36.3 & 9.2 & 8.0 & 3.9 & 1.0 & 1.0 & - \\
\hline V & $1.9 \times 10^{5}$ & a & 0.1 & 0.1 & 0.3 & 0.1 & a & a \\
\hline
\end{tabular}

a $<0.01 ;{ }^{b} \mathrm{Al}$ was used as the reference metal; ${ }^{\mathrm{c}} \mathrm{Mg}$ was used as the reference metal. 
reference. $\mathrm{Al}$ is traditionally considered to be a relatively stable soil tracer that is not affected by contamination. ${ }^{36}$ The selection of a metal as the normalization element is rather arbitrary and would lead to misleading conclusions if the metal were significantly enriched in the samples. For TSP and $\mathrm{PM}_{10}, \mathrm{Al}$ is the only a crustal-origin metal that is not enriched in the samples (Table 2). For $\mathrm{PM}_{2.5}$, it was not possible to use $\mathrm{Al}$ as the reference element because Al concentrations were under the limits of detection in all samples. $\mathrm{Mg}$ was considered a suitable reference element, as it was present in lower ratios in $\mathrm{PM}_{2.5}$ than in crustal material. The following expression was used for the calculations:

$$
\mathrm{EF}_{\mathrm{X}}=\frac{(\mathrm{X} / \mathrm{Ref})_{\mathrm{air}}}{(\mathrm{X} / \text { Ref })_{\text {crust }}}
$$

where $\mathrm{EF}_{\mathrm{X}}$ is the enrichment factor of species $\mathrm{X},(\mathrm{X} / \mathrm{Ref})_{\text {air }}$ is the ratio of species $X$ to the reference metal in the aerosol sample and $(\mathrm{X} / \mathrm{Ref})_{\text {crust }}$ is the ratio of species $\mathrm{X}$ to the reference metal in the earth crust. The values for the composition of the earth crust were the same as those used in our previous work ${ }^{13}$ and related papers. ${ }^{37}$

The interpretation of EF is based on the fact that metals originating from well-defined sources, such as the earth crust, can be distinguished from other metals derived from anthropogenic processes. ${ }^{36,38,39}$ Because crustal metals are also present in direct exhaust emissions from vehicles, the choice of a reference material is rather difficult. However, the dependence of calculated values on this choice does not (in general) affect the conclusions that may be obtained from EF factors.

The EF values calculated in this work are shown in Table 2. $\mathrm{Zn}$ and $\mathrm{Cu}$ have EF values higher than 10 and may be considered to be of anthropogenic origin in all samples of particulate matter. As previously noted, $\mathrm{Cu}$ is typically linked to the abrasion of brakes, and $\mathrm{Zn}$ is generally linked to tire wear. These values are $c a$. 10 times higher than those obtained from our previous studies at the bus station. ${ }^{13}$ The EF results are in close agreement with the calculated relative concentrations. Other metals, such as $\mathrm{Ni}, \mathrm{Cd}$ and $\mathrm{Pb}$, which are frequently identified as being of anthropogenic origin, were under their limits of detection and thus were not included in these calculations.

\section{Trace metal dry deposition fluxes}

Dry deposition can be an important mechanism for removing pollutants in the absence of precipitation and is characterized by the deposition velocity. The net flux of a species to the surface is proportional to the concentration of the species. ${ }^{40}$ The deposition processes include gravitational settling, impaction and diffusion, ${ }^{41}$ and these processes are dependent upon wind speed, humidity, viscosity and surface roughness. Dry deposition velocities are higher for coarse particles than for fine particles, and a range of settling velocities has been reported in the literature..$^{23,40,42,43}$

In this work, dry deposition fluxes were calculated using an approximate model: $:^{38,40}$

$\mathrm{F}_{\mathrm{d}}=\mathrm{V}_{\mathrm{d}} \mathrm{C}_{\mathrm{i}}$

where $\mathrm{F}_{\mathrm{d}}$ is the dry deposition flux, $\mathrm{C}_{\mathrm{i}}$ is the trace metal geometric mean concentration and $\mathrm{V}_{\mathrm{d}}$ is the elemental deposition velocity. The settling velocities reported by Yi et $a l .{ }^{43}$ were adopted. They determined their velocities by dividing measured fluxes by measured airborne concentrations. Flux measurements were performed with a smooth surrogate surface on an automated dry deposition sampler, and ambient particle concentrations were collected using a dichotomous sampler and analyzed by X-ray fluorescence spectrometry. ${ }^{43}$ It should be emphasized, however, that the flux calculations might vary by more than one order of magnitude due to differences in the methods used and the uncertainties in $\mathrm{V}_{\mathrm{d}}$. Approximated values were estimated in order to compare our current data with data obtained in the bus station study ${ }^{13}$ and in several locations in Salvador City (Bahia State, Brazil). ${ }^{23}$ Calculated values are presented in Table 3.

When considering the calculated flux of TSP as the overall dry deposition, the main contribution is due to the crustal elements $\mathrm{Ca}, \mathrm{Mg}$ and $\mathrm{Fe}$. These fluxes are at least one order of magnitude greater than those ones of the metals of anthropogenic origin ( $\mathrm{Mn}, \mathrm{Zn}$ and $\mathrm{Cu}$ ). For TSP and $\mathrm{PM}_{10}$, $\mathrm{Ca}$ shows a higher flux due to the higher concentration. Considering the uncertainties and the wide range of dry settling velocities used in the literature, these results are in a range that is equivalent to the previously reported values taken at the bus station ${ }^{13}$ and at other locations in Brazil and worldwide. ${ }^{23,40,43}$ This was an expected result since dry deposition fluxes depend on element concentrations, which do not drastically differ for the studied areas.

In the fine particle fraction, the dry deposition flux for Ca was considerably lower than in the previously described fractions ( $c a .10$ times lower than in the TSP fraction). For primarily anthropogenic elements that are associated with smaller particle sizes, the dry deposition fluxes are mainly lower in the TSP and $\mathrm{PM}_{10}$ fractions due to the smaller concentrations of these elements compared to the crustal elements. When comparing the deposition flux of the elements in the different fractions, rates of flux for 
Table 3. Estimated trace element dry deposition fluxes in the André Rebouças Tunnel $\left(\mathrm{F}_{\mathrm{d}}\right)$. Dry settling velocities $\left(\mathrm{V}_{\mathrm{d}}\right)$ are from reported literature data ${ }^{40,43}$

\begin{tabular}{|c|c|c|c|c|c|c|c|}
\hline TSP $(6 \mathrm{~h})$ & $\mathrm{Ca}^{\mathrm{a}}$ & $\mathrm{Mg}$ & $\mathrm{Fe}^{\mathrm{a}}$ & $\mathrm{Mn}$ & $\mathrm{Zn}$ & $\mathrm{Cu}$ & $\mathrm{Al}$ \\
\hline Mean concentration / $\left(\mathrm{ng} \mathrm{m}^{-3}\right)$ & 5037.6 & 1319.3 & 4101.1 & 53.8 & 178.6 & 182.1 & 1095.5 \\
\hline Dry settling velocity $(\mathrm{Vd}) /\left(\mathrm{cm} \mathrm{s}^{-1}\right)$ & $1.839^{\mathrm{b}}$ & $4.6^{\mathrm{a}}$ & $1.405^{\mathrm{b}}$ & $1.1^{\mathrm{a}}$ & $3^{\mathrm{a}}$ & $3^{\mathrm{a}}$ & $1.1^{\mathrm{a}}$ \\
\hline Dry deposition flux $(\mathrm{Fd}) /\left(\mathrm{mg} \mathrm{m}^{-2} \mathrm{yr}^{-1}\right)$ & 17529.2 & 11482.7.1 & 10902.7 & 11.9 & 727.4 & 1013.8 & 2280.1 \\
\hline \multicolumn{8}{|l|}{$\mathrm{PM}_{10}(6 \mathrm{~h})$} \\
\hline Mean concentration / $\left(\mathrm{ng} \mathrm{m}^{-3}\right)$ & 2996.8 & 803.2 & 994.4 & 13.8 & 39.1 & 87.4 & 429.7 \\
\hline Dry settling velocity $(\mathrm{Vd}) /\left(\mathrm{cm} \mathrm{s}^{-1}\right)$ & $1.839^{\mathrm{b}}$ & $4.6^{\mathrm{a}}$ & $1.405^{\mathrm{b}}$ & $1.1^{\mathrm{a}}$ & $3^{\mathrm{a}}$ & $3^{\mathrm{a}}$ & $1.1^{\mathrm{a}}$ \\
\hline Dry deposition flux $(\mathrm{Fd}) /\left(\mathrm{mg} \mathrm{m}^{-2} \mathrm{yr}^{-1}\right)$ & 10427.9 & 6991.0 & 2643.6 & 28.6 & 238.4 & 495.9 & 894.4 \\
\hline \multicolumn{8}{|l|}{$\mathrm{PM}_{2.5}(24 \mathrm{~h})$} \\
\hline Mean concentration / $\left(\mathrm{ng} \mathrm{m}^{-3}\right)$ & 59.5 & 21.2 & 321 & 4.4 & 20.8 & 47.2 & - \\
\hline Dry settling velocity $(\mathrm{Vd}) /\left(\mathrm{cm} \mathrm{s}^{-1}\right)$ & $0.317^{\mathrm{b}}$ & $23.1^{\mathrm{a}}$ & $0.385^{\mathrm{b}}$ & $12.3^{\mathrm{a}}$ & $2.8^{\mathrm{a}}$ & $2.8^{\mathrm{a}}$ & $12.3^{\mathrm{a}}$ \\
\hline Dry deposition flux $(\mathrm{Fd}) /\left(\mathrm{mg} \mathrm{m}^{-2} \mathrm{yr}^{-1}\right)$ & 142.9 & 3704.9 .0 & 935.3 & 413.7 & 521.3 & 999.4 & - \\
\hline
\end{tabular}

Reference 43; 'beference 40.

anthropogenic metals $(\mathrm{Zn}$ and $\mathrm{Cu})$ are relatively higher in the $\mathrm{PM}_{2.5}$ fraction. Again, this finding is a result of the trace metal levels and distribution.

\section{Statistical analysis}

A multivariate statistical approach was applied to determine the relationship between measured trace metals.
A combination of Spearman's correlation coefficients, cluster analysis and principal component analysis (PCA) were used. Spearman's correlation coefficients were calculated using the individual metal concentrations and are presented in Table 4.

For $\mathrm{PM}_{10}$ and total particulate matter, high correlations were obtained with $\mathrm{Ca}, \mathrm{Mg}$ and $\mathrm{Al}$ (0.89-0.99). The correlation of $\mathrm{Ca}$ and $\mathrm{Mg}$ with $\mathrm{Fe}$ was poor (0.36-0.55),

Table 4. Spearman's correlation factors calculated for metals in TSP, $\mathrm{PM}_{10}$ and $\mathrm{PM}_{2.5}$ samples collected from the André Rebouças Tunnel

\begin{tabular}{|c|c|c|c|c|c|c|c|c|c|}
\hline TSP & $\mathrm{Ca}$ & $\mathrm{Mg}$ & $\mathrm{Mn}$ & $\mathrm{Fe}$ & $\mathrm{Zn}$ & $\mathrm{Cu}$ & $\mathrm{Cr}$ & $\mathrm{Al}$ & $\mathrm{V}$ \\
\hline$\overline{\mathrm{Ca}}$ & 1 & & & & & & & & \\
\hline $\mathrm{Mg}$ & 0.89 & 1 & & & & & & & \\
\hline $\mathrm{Mn}$ & 0.44 & 0.31 & 1 & & & & & & \\
\hline $\mathrm{Fe}$ & 0.55 & 0.37 & 0.87 & 1 & & & & & \\
\hline $\mathrm{Zn}$ & 0.61 & 0.42 & 0.58 & 0.73 & 1 & & & & \\
\hline $\mathrm{Cu}$ & 0.58 & 0.45 & 0.55 & 0.67 & 0.35 & 1 & & & \\
\hline $\mathrm{Cr}$ & 0.61 & 0.40 & 0.85 & 0.98 & 0.74 & 0.69 & 1 & & \\
\hline $\mathrm{Al}$ & 0.92 & 0.76 & 0.66 & 0.76 & 0.70 & 0.66 & 0.79 & 1 & \\
\hline $\mathrm{V}$ & 0.42 & 0.21 & 0.46 & 0.54 & 0.41 & 0.59 & 0.52 & 0.5 & 1 \\
\hline $\mathrm{PM}_{10}$ & $\mathrm{Ca}$ & $\mathrm{Mg}$ & $\mathrm{Mn}$ & $\mathrm{Fe}$ & $\mathrm{Zn}$ & $\mathrm{Cu}$ & $\mathrm{Al}$ & $\mathrm{V}$ & \\
\hline $\mathrm{Ca}$ & 1 & & & & & & & & \\
\hline $\mathrm{Mg}$ & 0.99 & 1 & & & & & & & \\
\hline $\mathrm{Mn}$ & 0.35 & 0.34 & 1 & & & & & & \\
\hline $\mathrm{Fe}$ & 0.37 & 0.36 & 0.93 & 1 & & & & & \\
\hline $\mathrm{Zn}$ & 0.64 & 0.60 & 0.50 & 0.58 & 1 & & & & \\
\hline $\mathrm{Cu}$ & 0.55 & 0.53 & 0.30 & 0.36 & 0.48 & 1 & & & \\
\hline $\mathrm{Al}$ & 0.95 & 0.97 & 0.41 & 0.45 & 0.57 & 0.60 & 1 & & \\
\hline $\mathrm{V}$ & 0.19 & 0.15 & 0.34 & 0.33 & 0.28 & 0.39 & 0.15 & 1 & \\
\hline $\mathrm{PM}_{2.5}$ & $\mathrm{Ca}$ & $\mathrm{Mg}$ & $\mathrm{Mn}$ & $\mathrm{Fe}$ & $\mathrm{Zn}$ & $\mathrm{Cu}$ & $\mathrm{V}$ & & \\
\hline $\mathrm{Ca}$ & 1 & & & & & & & & \\
\hline $\mathrm{Mg}$ & 0.58 & 1 & & & & & & & \\
\hline $\mathrm{Mn}$ & 0.44 & 0.42 & 1 & & & & & & \\
\hline $\mathrm{Fe}$ & 0.32 & 0.49 & 0.74 & 1 & & & & & \\
\hline $\mathrm{Zn}$ & 0.49 & 0.37 & 0.63 & 0.58 & 1 & & & & \\
\hline $\mathrm{Cu}$ & -0.26 & -0.13 & 0.05 & 0.05 & -0.35 & 1 & & & \\
\hline $\mathrm{V}$ & 0.30 & -0.09 & 0.2 & 0.33 & 0.40 & -0.30 & 1 & & \\
\hline
\end{tabular}


which is an important difference when comparing these results with those obtained at the bus station. ${ }^{13}$ These results indicate that $\mathrm{Ca}, \mathrm{Mg}$ and $\mathrm{Al}$ are probably due to the resuspension of dust, while Fe may also have additional source. A similar conclusion is obtained from Figure 1 in which $\mathrm{Al}, \mathrm{Mg}$ and $\mathrm{Ca}$ are grouped in the same sub-group, and Fe is closely related to $\mathrm{Cr}$ (in TSP) and $\mathrm{Mn}$ (in TSP and $\mathrm{PM}_{10}$ ) (correlation factors in the range of 0.87-0.98).
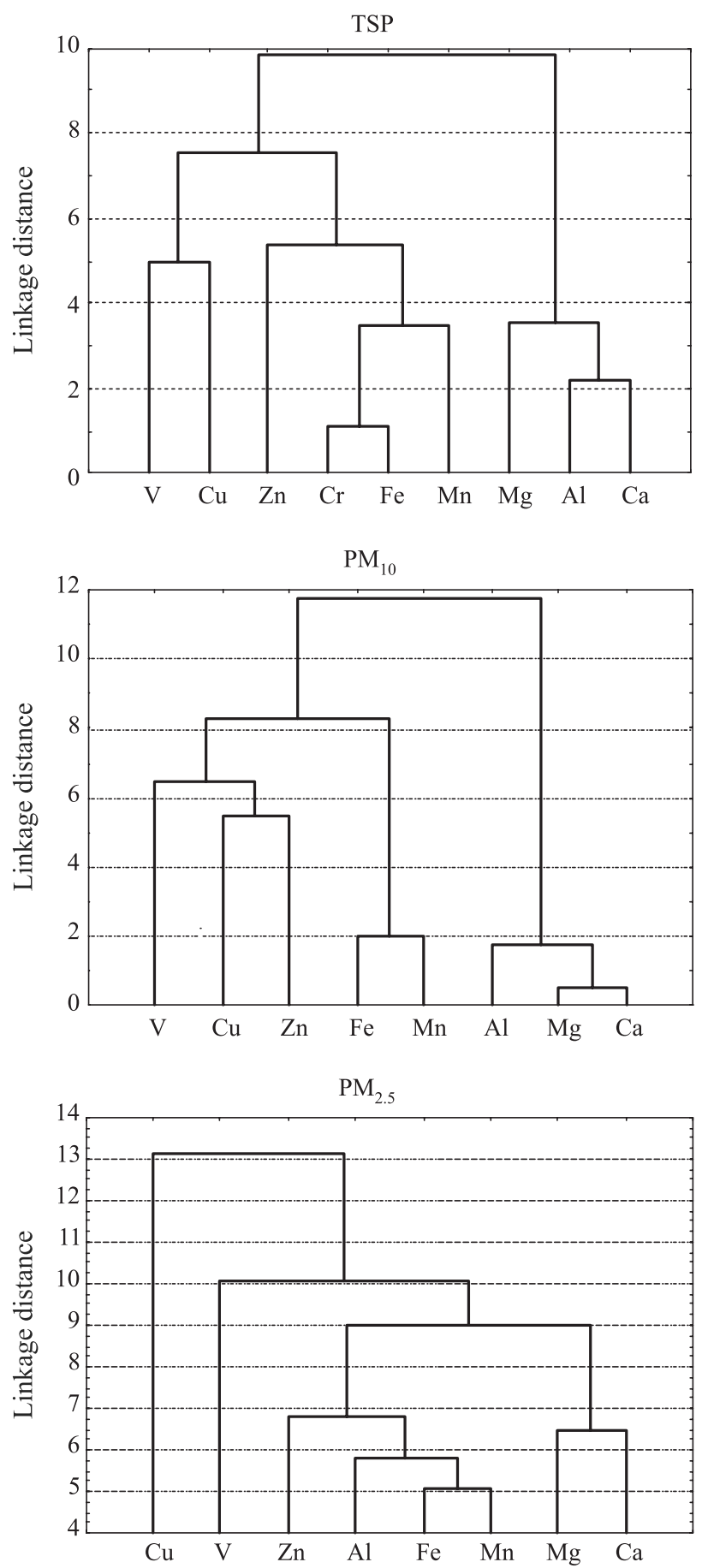

Figure 1. Cluster analysis at $95 \%$ confidence level for TSP, $\mathrm{PM}_{10}$ and $\mathrm{PM}_{2.5}$ samples collected from the André Rebouças Tunnel.
As previously cited, $\mathrm{Fe}$ and $\mathrm{Mn}$ are important elements of brake wear, and their levels were determined in the exhaust of gasoline-fueled vehicles. Anthropogenic elements $(\mathrm{Zn}$ and $\mathrm{Cu})$ have low correlation factors. This suggests that they have different emission sources.

Principal component analysis gave similar results. Two factors showing eigenvalues higher than 1 (accounting for a total of $81 \%$ of the data variability) were identified for TSP. One factor was attributed to soil dust based on the presence of crustal elements $(\mathrm{Ca}, \mathrm{Mg}$ and $\mathrm{Al})$. The other factor concerned the high loadings of $\mathrm{Mn}, \mathrm{Fe}$, $\mathrm{Zn}$ and $\mathrm{Cr}$, which characterize the vehicular traffic factor. For $\mathrm{PM}_{10}$, three factors with eigenvalues higher than 1 were obtained, thereby explaining $79 \%$ of data variance. The first factor was attributed to soil dust $(\mathrm{Ca}, \mathrm{Mg}$ and $\mathrm{Al}$ ), the second factor was attributed to high loadings of Fe and Mn and may be associated to vehicular traffic and the third factor $(\mathrm{V})$ may be attributed to diesel fuel and oil combustion.

For fine particles, the correlation factor between $\mathrm{Ca}$ and $\mathrm{Mg}$ was relatively low (0.58), and $\mathrm{Fe}$ was found to be related to $\mathrm{Mn}(0.74)$. The weak correlation between metals may be indicative of a variety of sources related to vehicular flux. Principal components analysis showed three factors with eigenvalues higher than 1 , which account for $71 \%$ of the data variability. These factors are related to natural inputs $(\mathrm{Ca}$ and $\mathrm{Mg}$ ), vehicular emissions $(\mathrm{Mn}, \mathrm{Fe}$ and $\mathrm{Zn}$ ) and diesel and oil combustion (V).

Principal component analysis, Figure 2, clearly suggests that natural sources, dust resuspension and vehicular traffic may be related to particulate matter. Nevertheless, the relative contributions of these components are different: for TSP and $\mathrm{PM}_{10}$, the soil dust and, to a lesser extent, the marine aerosols are the main sources of contribution, while for $\mathrm{PM}_{2.5}$ fraction, the soil dust and vehicular emissions contribute to a similar extent.

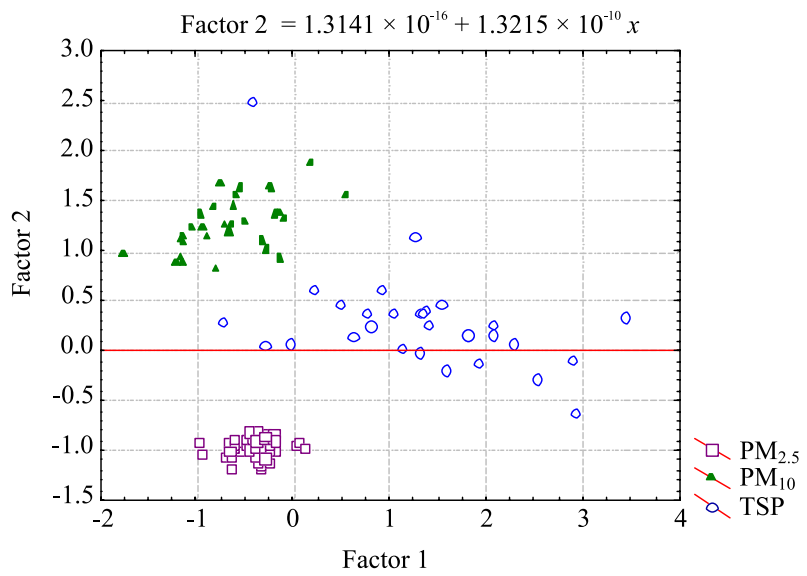

Figure 2. Principal component analysis for TSP, $\mathrm{PM}_{10}$ and $\mathrm{PM}_{2.5}$ samples. 
When the present results are compared with results obtained for TSP and $\mathrm{PM}_{10}$ at the bus station in the Rio de Janeiro Metropolitan Area ${ }^{13}$ and the $\mathrm{PM}_{10}$ at the Lapa Bus Station in Salvador ${ }^{23}$ using the same analytical method, several differences are observed. Enrichment factors for $\mathrm{Cu}$ and $\mathrm{Zn}$ in both bus stations were in the range 20-30, while the values obtained in this work were approximately an order of magnitude higher. Also, in both bus stations, in the high diesel-fueled vehicle fraction, $\mathrm{Cu}$ and $\mathrm{Zn}$ were highly correlated, while no significant correlation was observed in the present work.

\section{Conclusions}

Exhaust emissions of metals were determined in coarse and fine particulate matter collected in a location characterized by light-duty vehicular flux. The results for coarse particles are significantly different from those obtained for fine particles, confirming that they originate from different sources. For coarse particles, $\mathrm{Ca}, \mathrm{Mg}$ and $\mathrm{Al}$ may be attributed to marine aerosols and the resuspension of dust, while $\mathrm{Fe}$ and anthropogenic metals ( $\mathrm{Zn}$ and $\mathrm{Cu}$ ) may originate from brake and tire wear. In fine particulate matter, the presence of these metals may be attributed to the corrosion of internal vehicular components and exhaust pipes.

\section{Supplementary Information}

Supplementary information concerning the experimental procedures is available free of charge at http://jbcs.sbq.org.br as a PDF file.

\section{Acknowledgments}

This study was partly funded by the Conselho Nacional de Desenvolvimento Científico e Tecnológico (CNPq) and the Coordenação de Aperfeiçoamento de Pessoal de Nível Superior (CAPES). We would like to thank the LMT of the Federal University of Rio de Janeiro for their collaboration. Albino José Kalab Leiroz, Nauberto Rodrigues Pinto, Pedro Paulo Pereira, Pedro Henrique Leite dos Santos, Renan de Souza and Marcos Dufles are thanked for providing the facilities to perform the sampling of the motor exhaust. We are grateful to Marcos Menezes and Luiz Carlos de Oliveira of FIOCRUZ for lending us the high volume samplers and to Pierre Batista de Almeida Jr. for his support in the interpretation of meteorological data.

\section{References}

1. http://www.antt.gov.br/inventario/documentos/ inventarionacional20110209.pdf accessed in May 2011.

2. http://www.denatran.gov.br/ accessed in May 2011.

3. http://www.inea.rj.gov.br/fma/qualidade-ar.asp accessed in May 2011.

4. http://www.ima.al.gov.br/legislacao/resolucoes-conama accessed in May 2011.

5. Korn, M. G. A.; dos Santos, D. S. S.; Welz, B.; Vale, M. G. R.; Teixera, A. P.; Lima, D. C.; Ferreira, S. L. C.; Talanta 2007, $73,1$.

6. Du, B.; Wei, Q.; Wang, S.; Yu, W.; Talanta 1997, 44, 1803.

7. Aucelio, R. Q.; Curtius, A. J.; J. Anal. At. Spectrom. 2002, 17, 242.

8. Saint'Pierre, T. D.; Dias, L. F.; Maia, S. M.; Curtis, A. J.; Spectrochim. Acta, Part B 2005, 59, 551.

9. Handler, M.; Puls C.; Zbiral, J.; Marr, I.; Puxbaun, H.; Limbeck, A.; Atmos. Environ. 2008, 42, 2173.

10. Fabretti, J. F.; Sauret, N.; Gal, J. F.; Maria, P. C.; Scarer, U.; Atmos. Res. 2009, 94, 320.

11. Da Silva, L. I.; Sarkis, J. E. de S.; Zotin, F. M.Z.; Carneiro, M. C.; Alcover Neto, A.; da Silva, A. S. A. G.; Cardoso, M. J. B.; Monteiro, M. I. C.; Chemosphere 2008, 71, 677.

12. Toledo, V. E.; Almeida Jr., P.B.; Quiterio, S. L., Arbilla, G.; Moreira, A.; Escaleira, V.; Moreira, J. C.; Environ. Monit. Assess. 2008, 139, 49.

13. Loyola, J.; Arbilla, G.; Quiterio, S.L.; Escaleira, V.; Bellido, A. V.; J. Braz. Chem Soc. 2009, 20, 1350.

14. Soluri, D. S.; Godoy, M. L. D. P.; Godoy, J. M.; J. Braz. Chem Soc. 2007, 18, 839.

15. Godoy, M. L. D. P.; Godoy, J. M.; Roldão, L. A.; Soluri, D.; Donagemma, R. A.; Atmos. Environ. 2009, 43, 2366.

16. Miranda, R.; Tomaz, E.; Atmos. Res. 2008, 87, 147.

17. Miranda, R. M.; Andrade, M. F.; Atmos. Environ. 2005, 39, 6188.

18. Gioia, S. M. L. C.; Babinski, M.; Weiss, D. J.; Kerr, A. A. F.S.; Atmos. Res. 2010, 98, 478.

19, http://www.ibge.gov.br/cidadesat/link.php?uf=rj accessed in May 2011.

20. http:// www.detran.gov.br/estatisticas accessed in May 2011.

21. Almeida, J. C.; Moreira. A.; Moreira, L.; Arbilla.; Tchê Química 2004, 5, 13.

22. U. S. Environmental Protection Agency (U. S. EPA), Compendium of Methods for the Determination of Inorganic Compounds in Ambient Air Compendium, Method IO-2.1, Cincinnati, OH 45268, 1999.

23. Pereira, P. A. P.; Lopes, W. A.; Carvalho, L. S.; Rocha, G. O.; Bahia, N. C.; Loyola, J.; Quiterio, S. L.; Escaleira, V.; Arbilla, G.; Rade, J. B.; Atmos. Environ. 2007, 41, 7837. 
24. U. S. Environmental Protection Agency (U. S. EPA), Determination of Metals in Ambient Particulate Matter using Inductively Coupled Plasma (ICP) Spectroscopy, Method IO-3.4, Cincinnati, OH 45268, 1999.

25. Ribani, M.; Bottoli, C. B. G.; Jardim, I. C. S. F.; Melo, L. F. C.; Quim. Nova 2004, 27, 780.

26. López, M. C.; Aarnink, A. J.; Zhao, Y.; Calvet, S.; Torres, G.; Environ. Pollution 2010, 158, 17.

27. Lough, G.; Schauer, J. J.; Park, J.; Shafer, M. M.; De Minter, J. T.; Weinstein, J. P.; Environ. Sci. Technol. 2005, 39, 826.

28. Thorpe, A ; Harrison; R. M.; Sci. Total. Environ. 2008, 400, 282.

29. Silva, M. F.; Emissão de Metais por Veículos Automotores e seus Efeitos à Saúde Pública, MSc Dissertation, Faculdade de Saúde Pública, Universidade de São Paulo, São Paulo, Brasil, 2007, available at http://www.teses.usp.br/teses/disponiveis/6/6134/ tde-08112007-152445/en.php accessed in May 2011.

30. Arditsoglou, A.; Samara, C.; Chemosphere 2005, 59, 669.

31. Lim, M. C. H.; Ayoko, G. A.; Morawska, L.; Ristovski, Z. D.; Jayaratne, E. R.; Fuel 2007, 86, 1831.

32. Brandão, G. P.; Campos, R. C.; Castro, E. V. R.; Jesus, H. C.; Spectrochim. Acta, Part B 2008, 63, 880.

33. Projahn, H. D.; Steeg, U.; Sanders, J.; Vanclay, E.; Anal. Bioanal. Chem. 2004, 378, 1083.
34. Roldan, P. S.; Alcântara, I. L.; Padilha, C. C. F.; Padilha, P. M.; Fuel 2005, 84, 305.

35. Santos, S. D.; Korn, M. G. A.; Guida, M. A. B.; Santos, G. L.; Lemos, V. A.; Texeira, L. S. G.; J. Braz. Chem. Soc. 2011, 22, 557.

36. Na, K.; Cocker, D. R.; Atmos. Res. 2009, 93, 793.

37. http://www.webelements.com/calcium/geology.html accessed in May 2011.

38. Fang, G.C.; Wu, Y. S.; Huang, S. H.; Rau, J. Y.; Chemosphere. 2004, 56, 509

39. Weckwerth, G.; Atmos. Environ. 2001, 35, 5525.

40. Fang, G. C.; A Study of Mass Size Distributions and Particle Deposition Velocities in Ambient Air, $\mathrm{PhD}$ Thesis of Illinois Institute of Technology, Chicago, Illionis, 1992, p. 220.

41. Ottley, C. J.; Harrison, R. M.; Atmos. Environ. 1993, 27, 685.

42. Sakata, M.; Tani, Y.; Takagi, T.; Atmos. Environ. 2008, 42, 5913.

43. Yi, S. M.; Shahin, U.; Sivadechathep, J.; Sofuoglu, S. C.; Holsen, T. M.; Atmos. Environ. 2001, 35, 1133.

Submitted: July 11, 2011

Published online: February 7, 2012 